\title{
Study of the embryofeto-toxicity of Crown-of-Thorns (Euphorbia milii) latex, a natural molluscicide
}

C.A.M. Souza, R.R. de-Carvalho, S.N. Kuriyama, I.B. Araujo, R.P. Rodrigues, R.S. Vollmer, E.N. Alves and F.J.R. Paumgartten
Laboratório de Toxicologia Ambiental, Departamento de Ciências Biológicas, Escola Nacional de Saúde Pública, FIOCRUZ, Rio de Janeiro, RJ, Brasil

\section{Correspondence \\ F.J.R. Paumgartten \\ Laboratório de Toxicologia \\ Ambiental \\ Departamento de Ciências \\ Biológicas \\ ENSP, Fundação Oswaldo Cruz \\ Av. Brasil, 4365 \\ 21045-900 Rio de Janeiro, RJ \\ Brasil}

Research supported by $\mathrm{CNPq}$ and PAPES-FIOCRUZ. F.J.R. Paumgartten and S.N. Kuriyama are recipients of CNPq fellowships.

$\ldots \ldots \ldots \ldots \ldots \ldots \ldots$

Received March 13, 1997 Accepted August 25, 1997

\begin{abstract}
The crude latex of Crown-of-Thorns (Euphorbia milii var. hislopii) is a potent plant molluscicide and a promising alternative to the synthetic molluscicides used in schistosomiasis control. The present study was undertaken to investigate the embryofeto-toxic potential of E. milii latex. The study is part of a comprehensive safety evaluation of this plant molluscicide. Lyophilized latex $(0,125,250$ and $500 \mathrm{mg} / \mathrm{kg}$ body weight) in corn oil was given by gavage to Wistar rats $(\mathrm{N}=100)$ from days 6 to 15 of pregnancy and cesarean sections were performed on day 21 of pregnancy. The numbers of implantation sites, living and dead fetuses, resorptions and corpora lutea were recorded. Fetuses were weighed, examined for external malformations, and fixed for visceral examination, or cleared and stained with Alizarin red S for skeleton evaluation. A reduction of body weight minus uterine weight at term indicated that $E$. milii latex was maternally toxic over the dose range tested. No latex-induced embryolethality was noted at the lowest dose $(125 \mathrm{mg} / \mathrm{kg})$ but the resorption rate was markedly increased at $250 \mathrm{mg} / \mathrm{kg}(62.5 \%)$ and $500 \mathrm{mg} / \mathrm{kg}(93.4 \%)$. A higher frequency of fetuses showing signs of delayed ossification (control: $17.4 \% ; 125 \mathrm{mg} / \mathrm{kg}: 27.4 \%$ and $250 \mathrm{mg} / \mathrm{kg}: 62.8 \% ; \mathrm{P}<0.05 v s$ control) indicated that fetal growth was retarded at doses $\geq 125 \mathrm{mg}$ latex $/ \mathrm{kg}$ body weight. No increase in the proportion of fetuses with skeletal anomalies was observed at the lowest dose but the incidence of minor skeletal malformations was higher at $250 \mathrm{mg} / \mathrm{kg}$ body weight (control: 13.7\%; $125 \mathrm{mg} / \mathrm{kg}$ : 14.8\%; $250 \mathrm{mg} / \mathrm{kg}$ : 45.7\%; P<0.05 vs control). Since a higher frequency of minor malformations was noted only at very high doses of latex which are embryolethal and maternally toxic, it is reasonable to conclude that this plant molluscicide poses no teratogenic hazard or, at least, that this possibility is of a considerably low order of magnitude.
\end{abstract}

Key words

- Euphorbiaceae

- Embryofeto-toxicity

- Plant molluscicides

- Euphorbia milii

- Reproductive toxicity

- Safety evaluation 


\section{Introduction}

In addition to treating the affected individuals, one of the most effective and rapid means of reducing schistosomiasis transmission is snail control with molluscicides. Desirable attributes of a molluscicide to be used in public health programs are a high activity and specificity for snails, a low toxicity to mammalian species, stability under different environmental and storage conditions, safety to the applicator, and low cost (1). None of the synthetic molluscicides currently available meet all these requirements and only one, niclosamide (Bayluscide ${ }^{\circledR}$ ), is recommended by the WHO for large-scale use in schistosomiasis control (1). Because developmental costs are high and the market is confined to the developing countries where the disease is endemic, no new molluscicide has been developed by the industry in recent years. However, considerable efforts have been made to find a plant molluscicide that would be at one time highly active, costeffective, safe, easy to apply and locally available in the endemic areas.

To date hundreds of botanical species have been screened for molluscicidal activity but the application of crude plant material to snail habitats, with very few exceptions (e.g., dried leaves of Ambrosia maritima and unripe berries of Phytolacca dodecandra), has been unsuccessful (2). Within this context, the crude latex of "Crown-of-Thorns" (Euphorbia milii var. hislopii Des Moul. ex Boiss, syn. E. splendens) seems to be one of the most promising plant molluscicides tested so far. It is active against the snails which are intermediate hosts of $S$. mansoni in the laboratory at concentrations as low as $0.5 \mathrm{ppm}$ (3) and under field conditions at concentrations between 5 and 12 ppm (4,5). Besides its remarkable potency, E. milii also presents some very interesting characteristics for a plant molluscicide: Crown-of-Thorns is a cosmopolitan plant easily cultivable in endemic areas, it yields a rather large amount of latex throughout the year and no marked geographic or seasonal variation in the molluscicidal activity of latex has been found $(6,7)$. An ecotoxicological study has also shown that latex is less harmful to non-target freshwater organisms than niclosamide (8).

The present study was carried out to investigate the teratogenic or embryofeto-toxic potential of $E$. milii latex in rats. The study is part of a more comprehensive toxicological evaluation of the health risks posed by this plant molluscicide.

\section{Material and Methods}

\section{Animals}

Male and virgin female Wistar rats from the Oswaldo Cruz Foundation Central Animal House breeding stock were used. The animals were housed in standard plastic cages with stainless steel cover lids and wood shavings as bedding, and kept under controlled temperature $\left(23 \pm 1^{\circ} \mathrm{C}\right)$, humidity (approximately $70 \%$ ), and dark-light cycle (lights on from 10:00 to 22:00 h). A pelleted diet (Nuvital ${ }^{\circledR}$, Nuvilab Ltd., Curitiba, PR, Brazil) and tap water were available ad libitum.

\section{Mating procedure}

Mating was performed by transferring two females to the cage of one male for $2 \mathrm{~h}$ (8:00 to 10:00 h). Copulation was confirmed by the presence of sperm in the vaginal smear and the day when spermatozoa were found was designated as day 0 of pregnancy.

\section{Plant material}

Latex of "Coroa-de-Cristo" ("Crown-ofThorns", Euphorbia milii var. hislopii, syn. E. splendens var. hislopii) was collected from plants cultivated in the district of Ilha do Governador, Rio de Janeiro, Brazil, from September to November, 1993. A longitudi- 
nal incision was made in the plant stem and the latex was collected into glass tubes which were then sealed, wrapped in aluminum foil, and immediately transported to the laboratory where it was lyophilized. Lyophilized latex was protected from light and stored in the refrigerator until further use. Under these storage conditions, E. milii latex keeps its molluscicidal potency for at least 18 months (7).

\section{Treatment}

The lyophilized latex was suspended in corn oil $\left(\right.$ Mazola $\left.^{\circledR}\right)$ and administered by gavage to rats $(\mathrm{N}=100)$ once a day from day 6 to day 15 of pregnancy. Three groups of pregnant rats were treated with different doses of lyophilized latex $(125,250$ and $500 \mathrm{mg} / \mathrm{kg}$ body weight) and a control group received only corn oil ( $3.75 \mathrm{~g} / \mathrm{kg}$ body weight). All rats were weighed on days 0,6 to 15 , and 21 of pregnancy.

\section{Cesarean section}

On day 21 of pregnancy the rats were anesthetized by ethyl ether inhalation and killed by decapitation. The gravid uterus was weighed with its contents. Living and dead fetuses, resorptions and corpora lutea were recorded. The number of implantation sites was determined by the method of Salewski (9). The fetuses were weighed, numbered with a marker pen, examined for external malformations and fixed in 5\% formalin solution. One-third of the fetuses of each litter, selected at random, were evaluated for visceral malformations using a microsectioning technique adapted from Sterz (10). Heart, lungs, thymus, spleen, liver and kidneys of fetuses which were microdissected were also weighed. The remaining fetuses were cleared with $\mathrm{KOH}$, stained with Alizarin red $S$ (11) and examined for skeletal abnormalities.

\section{Statistical analysis}

Data were analyzed by one-way analysis of variance or, alternatively, by the KruskalWallis test whenever the data did not fit a normal distribution. Differences between groups were tested by the two-sided Student $t$-test or Mann-Whitney U-test. Proportions were analyzed by the chi-square test or, alternatively, by the Fisher exact test. Statistical evaluation was performed using a MINITAB program (MTB, University of Pennsylvania, 1984), and differences were considered to be statistically significant at $\mathrm{P}<0.05$.

\section{Results}

As shown in Table 1, E. milii latex administered orally from pregnancy day 6 to day 15 caused a pronounced and dose-related decrease in maternal weight gain. Data also showed that treatment-induced weight gain deficits were still detectable at the end of pregnancy (day 21). Since gravid uterus weights were markedly reduced, latex-induced embryotoxic effects seemed to have contributed to the whole pregnancy weight gain deficits noted at the two highest doses (250 and $500 \mathrm{mg} / \mathrm{kg}$ ). Statistically significant reductions in body weight gain at the three dose levels were also found when uterine weights at term were deducted from overall pregnancy weight gain (Table 1), a finding suggesting that $E$. milii latex was maternally toxic over the dose range tested. At the two highest doses, latex caused slight to mild diarrhea and two dams treated with $500 \mathrm{mg} /$ $\mathrm{kg}$, and one dam treated with $250 \mathrm{mg} / \mathrm{kg}$ died between the second and fourth day of treatment. Despite these toxic effects on the dams, the ratio of pregnant (i.e., rats with implantation sites shown by Salewski's method) to sperm-positive treated females was not reduced by E. milii latex at any of the doses tested (Table 1). 
A higher proportion of resorptions per implantation site as well as an increase in the mean number of resorptions per litter were observed in the groups treated with the two highest doses of E. milii latex (Table 2). A parallel decrease in the number of live fetuses per litter was also noted (Table 2). The results therefore demonstrated that $E$. milii latex, at doses equal to or higher than 250 $\mathrm{mg} / \mathrm{kg}$, induced a high frequency of post-

Table 1 - Maternal weight gain of rats treated orally with Euphorbia milii latex $(0,125,250$ and $500 \mathrm{mg} / \mathrm{kg}$, po) on days 6 to 15 of pregnancy.

+Two rats treated with $500 \mathrm{mg} / \mathrm{kg}$ and one treated with $250 \mathrm{mg} / \mathrm{kg}$ died and were not included. \% of pregnant females was analyzed by the chi-square test. Maternal weight gain was analyzed by the Kruskal-Wallis test followed by the Mann-Whitney U-test. All other parameters were analyzed by one-way analysis of variance and the Student $t$-test. Data are reported as mean $\pm S D$. ${ }^{*} \mathrm{P}<0.05$ compared to control.

\begin{tabular}{|c|c|c|c|c|}
\hline \multirow[t]{2}{*}{ Treatment } & \multicolumn{4}{|c|}{ E. milii latex (mg/kg body weight) } \\
\hline & 0 & 125 & 250 & 500 \\
\hline Treated females & 29 & 24 & $28^{+}$ & $16^{+}$ \\
\hline Pregnant females & 19 & 21 & 22 & 13 \\
\hline Pregnant/treated females (\%) & 65.5 & 87.5 & 78.6 & 81.2 \\
\hline \multicolumn{5}{|l|}{ Maternal weight (g) } \\
\hline Day 0 & $236 \pm 16$ & $230 \pm 22$ & $229 \pm 11$ & $227 \pm 18$ \\
\hline Day 21 & $341 \pm 32$ & $326 \pm 35$ & $288 \pm 25^{*}$ & $250 \pm 20^{*}$ \\
\hline Gravid uterus weight (g) & $67.0 \pm 18.1$ & $63.8 \pm 23.1$ & $30.6 \pm 19.9^{*}$ & $4.6 \pm 8.1^{*}$ \\
\hline \multicolumn{5}{|l|}{ Maternal weight gain (g) } \\
\hline Days 6-11 & $9.8 \pm 4.1$ & $-9.8 \pm 4.8^{*}$ & $-23.8 \pm 8.7^{*}$ & $-31.1 \pm 6.7^{*}$ \\
\hline Days 6-15 & $26.0 \pm 7.4$ & $0.5 \pm 10.0^{*}$ & $-20.7 \pm 13.7^{*}$ & $-33.3 \pm 7.2^{*}$ \\
\hline Days $0-21$ & $104.6 \pm 23.5$ & $85.1 \pm 29.9$ & $52.0 \pm 28.2^{*}$ & $17.6 \pm 17.4^{*}$ \\
\hline Days 0-21 (minus uterus weight) & $37.7 \pm 16.6$ & $21.4 \pm 16.4^{*}$ & $19.9 \pm 11.7^{*}$ & $13.0 \pm 14.6^{*}$ \\
\hline
\end{tabular}

Table 2 - Effects of treatment with E. milii latex $(0,125,250$ and $500 \mathrm{mg} / \mathrm{kg}$, po) on days 6 to 15 of pregnancy on parameters assessed at the time of cesarean section of rats.

Percent resorptions was analyzed by the chi-square test. Numbers of corpora lutea, implantation sites and live fetuses per litter were analyzed by the Kruskal-Wallis test followed by the Mann-Whitney U-test. All other parameters were analyzed by one-way analysis of variance and the Student $t$-test. Data are reported as mean $\pm \mathrm{SD} .{ }^{*} \mathrm{P}<0.05$ compared to control.

\begin{tabular}{lcccc}
\hline Treatment & \multicolumn{4}{c}{ E. milii latex (mg/kg body weight) } \\
\cline { 2 - 5 } & 0 & 125 & 250 & 500 \\
\hline Corpora lutea & $11.9 \pm 1.8$ & $11.1 \pm 2.3$ & $10.4 \pm 2.8$ & $11.0 \pm 1.4$ \\
Implantation sites & $12.3 \pm 2.3$ & $11.8 \pm 13.7$ & $11.4 \pm 3.1$ & $11.0 \pm 2.8$ \\
Resorptions & 33 & 37 & 140 & 156 \\
Resorptions/implantations (\%) & 13.9 & 17.7 & $62.5^{*}$ & $93.4^{*}$ \\
Resorptions per litter & $1.8 \pm 1.9$ & $1.8 \pm 1.6$ & $6.4 \pm 3.4^{*}$ & $12.0 \pm 3.2^{*}$ \\
Live fetuses & 200 & 210 & 104 & 7 \\
Live fetuses per litter & $10.5 \pm 2.6$ & $10.0 \pm 4.1$ & $4.7 \pm 4.2^{*}$ & $0.4 \pm 12.1^{*}$ \\
Fetal weight (g) & & & & \\
$\quad$ Individual & $4.82 \pm 0.44$ & $4.66 \pm 0.51^{*}$ & $4.41 \pm 0.71^{*}$ & $3.44 \pm 0.66^{*}$ \\
$\quad$ Litter & $4.87 \pm 0.40$ & $4.66 \pm 0.45$ & $4.43 \pm 0.54$ & $3.55 \pm 0.37^{*}$
\end{tabular}


implantation losses.

A dose-dependent reduction of fetal body weight (Table 2) and a higher proportion of fetuses exhibiting signs of delayed ossification (Table 3) indicated that E. milii latex caused fetal growth retardation at doses $\geq$ $125 \mathrm{mg} / \mathrm{kg}$ body weight. Owing to the extremely high resorption rate $(93.4 \%)$ and to the very small number of living fetuses obtained, frequencies of fetal anomalies at the highest dose $(500 \mathrm{mg} / \mathrm{kg})$ were not included in the statistical evaluation of data and thus are not shown in Tables 3, 4, and 5 .

Edema, paleness, tail abnormalities (kinky tails and tails with a bent end), gastroschisis, and irregular positioning of hindpaws were occasionally observed in latex-exposed fetuses (Table 4). A higher proportion of fetuses with an abnormally shaped thymus (not related to the dose), as well as a dosedependent increase in the frequency of fetuses with an accessory lobe (seventh) in the liver, were the only treatment-related findings revealed by visceral examination (Table 4). No statistically significant $(\mathrm{P}>0.05$, ANOVA) alterations in fetal organ weight (mg; mean $\pm \mathrm{SD}$ ) were found after exposure to E. milii latex from days 6 to 15 of pregnancy: liver (control: $364 \pm 47 ; 125 \mathrm{mg} / \mathrm{kg}$ : $356 \pm 48 ; 250 \mathrm{mg} / \mathrm{kg}: 352 \pm 62$ ), spleen (control: $6.4 \pm 1.9 ; 125 \mathrm{mg} / \mathrm{kg}$ : $6.7 \pm 2.0 ; 250$ $\mathrm{mg} / \mathrm{kg}: 6.6 \pm 2.6$ ), thymus (control: $7.7 \pm 1.8$; $125 \mathrm{mg} / \mathrm{kg}: 8.2 \pm 1.5 ; 250 \mathrm{mg} / \mathrm{kg}: 7.7 \pm 1.8)$, lungs (control: $131.0 \pm 21.0 ; 125 \mathrm{mg} / \mathrm{kg}$ : $130.0 \pm 15.5 ; 250 \mathrm{mg} / \mathrm{kg}: 126.0 \pm 18.9$ ), heart (control: $31.9 \pm 5.4 ; 125 \mathrm{mg} / \mathrm{kg}: 31.0 \pm$ 7.2; $250 \mathrm{mg} / \mathrm{kg}: 30.9 \pm 7.2$ ) and kidneys (left, control: $11.6 \pm 2.3 ; 125 \mathrm{mg} / \mathrm{kg}$ : $11.1 \pm 1.7$; $250 \mathrm{mg} / \mathrm{kg}: 12.1 \pm 2.3$; right, control: $12.3 \pm$ 2.3; $125 \mathrm{mg} / \mathrm{kg}: 11.8 \pm 1.9 ; 250 \mathrm{mg} / \mathrm{kg}: 12.6$ \pm 2.6 )

The occurrence of gross structural skeletal abnormalities in fetuses exposed to $E$. milii latex from pregnancy day 6 to day 15 is shown in Table 5. No increase in the proportion of skeletal malformations was noted at the lowest dose tested, but the frequency of fetuses showing one or more abnormalities was higher at $250 \mathrm{mg}$ latex $/ \mathrm{kg}$ body weight. The overall increase in the occurrence of skeletal anomalies seemed to have resulted, to a large extent, from higher incidences of dislocated sternum (non-aligned sternebrae), additional ossification of the os interparieta-

Table 3 - Occurrence of signs of delayed ossification in the offspring of rats treated orally with $E$. milii latex $(0,125$ and $250 \mathrm{mg} / \mathrm{kg})$ on pregnancy days 6-15.

Signs of delayed ossification: not ossified (whole bone not stained); poorly ossified (whole bone is poorly ossified), and irregular spongy bones. Data were analyzed by the chi-square test or by the Fisher exact test. ${ }^{*} \mathrm{P}<0.05 \mathrm{vs}$ control. Because of the high resorption rate at the highest dose tested $(500 \mathrm{mg} / \mathrm{kg})$, only six fetuses of this group were available for skeleton examination, and thus they were not included in the table.

\begin{tabular}{lccc}
\hline \multirow{2}{*}{ Treatment } & \multicolumn{3}{c}{ E. milii latex (mg/kg body weight) } \\
\cline { 2 - 4 } & 0 & 125 & 250 \\
\hline Fetuses examined & 138 & 135 & 70 \\
Fetuses with signs of delayed ossification (\%) & 17.4 & $27.4^{*}$ & $62.8^{*}$ \\
\% fetuses with signs of delayed ossification in & & & \\
Skull & 8.7 & 5.9 & $34.3^{*}$ \\
Caudal vertebrae & 1.4 & $8.1^{*}$ & $32.8^{*}$ \\
Ribs & 0.7 & 0.7 & 2.8 \\
Forelimbs & 10.1 & $22.2^{*}$ & $45.7^{*}$ \\
Hindlimbs & 13.0 & 11.1 & $38.6^{*}$ \\
& & &
\end{tabular}

Table 4 - Occurrence of externally visible and visceral abnormalities in fetuses of rats treated orally with $E$. milii latex $(0,125$ and $250 \mathrm{mg} / \mathrm{kg}$ body weight) on days 6 to 15 of pregnancy.

Data were analyzed by the chi-square test or by the Fisher exact test. ${ }^{*} \mathrm{P}<0.05$ vs control. One fetus exposed to the highest dose $(500 \mathrm{mg} / \mathrm{kg})$ was not included in the table because it was the only one available for visceral examination in this group.

\begin{tabular}{lccc}
\hline Treatment & \multicolumn{3}{c}{ E. milii latex (mg/kg body weight) } \\
\cline { 2 - 4 } & 0 & 125 & 250 \\
\hline External examination (number of fetuses) & 200 & 210 & 104 \\
Gastroschisis (\%) & 0 & 0 & $1(1.0)$ \\
Edema (\%) & 0 & 0 & $2(1.9)$ \\
Paleness (\%) & 0 & 0 & $2(1.9)$ \\
Tail anomalies & & & \\
$\quad$ Bent tip (\%) & 0 & $8(3.8)$ & $1(1.0)$ \\
$\quad$ Kinky (\%) & 0 & $2(1.0)$ & $1(1.0)$ \\
Visceral examination (number of fetuses) & 62 & 62 & 28 \\
Abnormal shape of thymus (\%) & $1(1.6)$ & $6(9.7)^{*}$ & $2(7.1)^{*}$ \\
Extra lobe in liver (\%) & $2(3.2)$ & $20(32.3)^{*}$ & $14(50.0)^{*}$ \\
& & &
\end{tabular}


Table 5 - Occurrence of skeletal anomalies in fetuses of rats treated orally with $E$. milii latex (0, 125 and $250 \mathrm{mg} / \mathrm{kg}$ body weight) on days 6 to 15 of pregnancy.

Data were analyzed by the chi-square test or, alternatively, by the Fisher exact test. ${ }^{*} \mathrm{P}<0.05$ compared to control. The highest dose group was not included in the table because only six fetuses exposed to $500 \mathrm{mg} / \mathrm{kg}$ were examined. Historical control: data from all vehicle-control fetuses (distilled water or corn oil) of Wistar rats from the FIOCRUZ breeding stock evaluated in our laboratory. o.c., Ossification center.

\begin{tabular}{|c|c|c|c|c|}
\hline \multirow[t]{2}{*}{ Treatment } & \multirow[t]{2}{*}{$\begin{array}{c}\text { Historical } \\
\text { control }\end{array}$} & \multicolumn{3}{|c|}{$\begin{array}{c}\text { E. milii latex } \\
\text { (mg/kg body weight) }\end{array}$} \\
\hline & & 0 & 125 & 250 \\
\hline Fetuses examined & 780 & 138 & 135 & 70 \\
\hline Fetuses with anomalies (\%) & - & 13.7 & 14.8 & $45.7^{*}$ \\
\hline \multicolumn{5}{|l|}{$\begin{array}{l}\text { Percentage of fetuses showing anomalies in } \\
\text { Skull }\end{array}$} \\
\hline \multicolumn{5}{|l|}{ os parietalis } \\
\hline (incomplete ossif.) & 0.38 & 0 & 0 & 1.4 \\
\hline (additional ossif.) & 0.51 & 0.7 & 0.7 & 0 \\
\hline os interparietalis (additional ossif.) & 0.51 & 1.4 & 0 & $8.6^{*}$ \\
\hline os basisphenoidis (bone hole) & 0 & 0 & 0.7 & 0 \\
\hline os basioccipitalis (irregular shape) & 0 & 0 & 0 & 1.4 \\
\hline os frontalis (incomplete ossif.) & 0.51 & 0 & 0 & 1.4 \\
\hline os supraoccipitalis (additional ossif.) & 0 & 0 & 0 & 1.4 \\
\hline \multicolumn{5}{|l|}{ Vertebral column } \\
\hline $\begin{array}{l}\text { cervical vertebrae (o.c. constricted) } \\
\text { thoracic vertebrae }\end{array}$ & 0 & 0 & 0 & 1.4 \\
\hline (o.c. dumb bell) & 0 & 0 & 0.7 & 1.4 \\
\hline (o.c. asymmetric) & 0.13 & 0.7 & 0 & 0 \\
\hline (o.c. irregular shape) & 0 & 0 & 0.7 & 0 \\
\hline \multicolumn{5}{|l|}{ lumbar vertebrae } \\
\hline (o.c. missing) & 0 & 0 & 0.7 & 0 \\
\hline (o.c. dumb bell) & 0 & 0 & 0.7 & 0 \\
\hline Clavicula (bent) & 0 & 0 & 0.7 & 0 \\
\hline \multicolumn{5}{|l|}{ Sternum } \\
\hline (bent) & 0 & 2.2 & 0 & 1.4 \\
\hline (fused sternebrae) & 0 & 1.4 & 0 & 0 \\
\hline (dislocated) & 3.71 & 2.9 & 3.0 & $15.7^{*}$ \\
\hline \multicolumn{5}{|l|}{ Ribs } \\
\hline (missing) & 0.13 & 0 & 0 & 2.8 \\
\hline (extra cervical) & 0.90 & 0.7 & 0.7 & 0 \\
\hline (extra lumbar) & 0.77 & 0 & 3.0 & 0 \\
\hline (wavy) & 0.13 & 0 & 0 & 1.4 \\
\hline (discontinuous) & 0 & 0 & 0 & 1.4 \\
\hline \multicolumn{5}{|l|}{ Forelimbs } \\
\hline processus deltoideus (bone hole) & 0.90 & 0 & 1.5 & 2.8 \\
\hline humerus (bone hole) & 0 & 0 & 1.5 & $5.7^{*}$ \\
\hline scapula (bent) & 0.13 & 0 & 0 & 2.8 \\
\hline \multicolumn{5}{|l|}{ radius } \\
\hline (bent) & 0.13 & 0 & 0 & 2.8 \\
\hline (bone hole) & 0 & 0 & 0 & $4.3^{*}$ \\
\hline ulna (bent) & 0.13 & 0 & 0 & 2.8 \\
\hline \multicolumn{5}{|l|}{ Hindlimbs } \\
\hline polydactyly & 0 & 0.7 & 0 & 0 \\
\hline tibia (bent) & 0 & 2.9 & 0 & 0 \\
\hline
\end{tabular}

lis, hole in the humerus and hole in the radius.

\section{Discussion}

The maternal deaths as well as the decrease in overall weight gain during pregnancy, still apparent after subtraction of gravid uterus weight, clearly indicated that E. milii latex was maternally toxic over the dose range tested. These maternally toxic doses of latex also proved to be embryofetotoxic as revealed by the three outcomes evaluated: embryolethality, prenatal growth retardation and fetal malformations.

No post-implantation loss was noted at the lowest dose tested $(125 \mathrm{mg} / \mathrm{kg})$. Nonetheless, a sharp dose-related increase in the resorption rate, as well as a parallel decrease in the number of living fetuses, showed that embryolethality occurred at doses $\geq 250 \mathrm{mg}$ latex $/ \mathrm{kg}$.

Signs of prenatal growth retardation were observed in rats exposed to doses $\geq 125 \mathrm{mg}$ latex $/ \mathrm{kg}$. A dose-dependent increase in the frequency of fetuses exhibiting signs of delayed ossification indicated that $E$. milii latex caused retardation of fetal skeleton development at doses equal to or higher than $125 \mathrm{mg} /$ $\mathrm{kg}$. Latex-induced reductions in fetal body weight were only slight, and were not significant when the litter was taken as the statistical unit of analysis in the groups treated with 125 and $250 \mathrm{mg} / \mathrm{kg}$. Thus, in this case, as in previous experiments with other substances (12-14), the proportion of fetuses showing signs of delayed ossification proved to be a more sensitive indicator of prenatal growth retardation than fetal weight at term.

No increase in the occurrence of skeletal malformations was produced by E. milii latex at the lowest dose tested $(125 \mathrm{mg} / \mathrm{kg})$ but a higher frequency of skeletal anomalies was observed at doses as high as $250 \mathrm{mg} / \mathrm{kg}$. It is noteworthy that the E. milii latex-induced increase in skeletal malformations was mainly due to sternum dislocation (non- 
aligned sternebrae), the spontaneous frequency of which was high $(3.71 \%)$ in our rat strain. The second most frequent latex-induced skeletal anomaly, an additional ossification of the os interparietalis, was also found in $1.4 \%$ of fetuses exposed only to the vehicle (corn oil). The soft tissue and organ variations, such as abnormal shape of the thymus and accessory lobe in the liver, were also observed in vehicle-treated control rats. Thus, structural changes, the frequency of which was increased by $E$. milii latex, were also found in control fetuses and can be classified either as variations or minor malformations.

Dose-response relationships indicate that skeletal malformations were produced by $E$. milii latex only at doses $(\geq 250 \mathrm{mg} / \mathrm{kg}$ ) at which a marked embryolethality also occurred, and that prenatal growth retardation, already noted at the lowest dose tested (125 $\mathrm{mg} / \mathrm{kg}$ ), preceded both embryolethality and malformations. As pointed out by Manson and Kang (15), this dose-response pattern suggests that embryolethality and fetal skeletal malformations are different degrees of manifestations of the same primary insult to the embryo.

It is generally accepted that prenatal growth retardation and an increased resorption rate can be secondary to substanceinduced maternal toxicity (15). The role of maternal toxicity in causing fetal malformations, however, is still a matter of controversy. Khera $(16,17)$ reviewed the published data and examined the relationship between maternal toxicity, malformations and embryotoxicity. According to Khera (16), in the mouse, even malformations as severe as neural tube defects, fused or missing ribs, and fused or scrambled sternebrae could be caused by maternal toxicity. On the other hand, in rats and rabbits, Khera (17) found that maternal toxicity was associated with gross structural anomalies such as fused, supernumerary, missing or wavy ribs; fused, missing or split vertebrae, and fused, miss- ing or non-aligned sternebrae. Although most authors do not agree with Khera's conclusion that major malformations (e.g., exencephaly and open eyes) can be secondary to maternal toxicity, it is generally accepted that some variations and reversible minor structural anomalies (e.g., extra or wavy ribs) could result from maternal toxic effects $(15,18)$. Accordingly, it is believed that an increased frequency of variations and minor malformations found only at maternally toxic doses does not necessarily reflect the teratogenic potential of the test substance.

The embryofeto-toxic effects (prenatal growth retardation, embryolethality and higher frequencies of variations and minor malformations) observed in the present study seemed to be a consequence of $E$. milii latexinduced maternal toxicity.

Embryolethality and a higher frequency of minor skeletal malformations were observed only at doses $(\geq 250 \mathrm{mg}$ latex $/ \mathrm{kg}$ ) overtly toxic to the maternal organism. The same holds true for the $E$. milii-induced fetal growth retardation. This means that the embryo was not more susceptible to the toxic effects of latex than was the mother. Under such circumstances, it cannot be ascertained whether embryotoxicity resulted from a direct adverse effect on the embryo of doses coincidently toxic to the mother, or from a substance-induced disturbance of maternal metabolism or homeostasis. In any case, no increase in major gross structural anomalies was noted even at embryolethal and maternally toxic doses of latex, and thus it seems fair to conclude that this plant molluscicide poses no teratogenic hazard or, at least, that this possibility is of a considerably low order of magnitude.

In conclusion, the results of the present study indicate that the lyophilized latex of $E$. milii, given to rats by the oral route, caused prenatal growth retardation at doses $\geq 125$ $\mathrm{mg} / \mathrm{kg}$, and embryolethality at doses $\geq 250$ $\mathrm{mg} / \mathrm{kg}$ body weight. In addition, minor skeletal malformations were induced by $E$. milii 
latex at $250 \mathrm{mg} / \mathrm{kg}$, a maternally toxic dose at which a high proportion of embryonic deaths also occurred. Data also suggest that the noobserved-adverse-effect level (NOAEL) for embryofeto-toxicity is lower than $125 \mathrm{mg}$ lyophilized latex/kg body weight per day, and that a lowest-observed-effect level (LOEL) for gross structural malformations and embryolethality can be set at $250 \mathrm{mg}$ latex $/ \mathrm{kg}$ body weight per day by the oral route. Since E. milii latex has proved to be a potent plant molluscicide (3-5), unintentional human exposure to levels comparable to this LOEL is very unlikely to occur if the crude latex is to be used in snail control.

\section{References}

1. WHO (1993). The control of schistosomiasis: second report of the WHO Expert Committee. WHO Technical Report Series, 830. World Health Organization, Geneva.

2. Kloos H \& McCullough FS (1987). Plants with recognized molluscicidal activity. In: Mott KE (Editor), Plant Molluscicides. UNDP/World BankMHO, John Wiley \& Sons, New York, 45-108.

3. Vasconcellos MC \& Schall VT (1986). Latex of "Coroa de Cristo" (Euphorbia splendens): an effective molluscicide. Memórias do Instituto Oswaldo Cruz, 81: 475476.

4. Baptista DF, Vasconcellos MC, Lopes FE, Silva IP \& Schall VT (1992). Evaluation of the molluscicidal property of Euphorbia splendens var. hislopii (NEB) (Euphorbiaceae). 2. Investigation in lotic habitat. $\mathrm{Me}$ mórias do Instituto Oswaldo Cruz, 87: 549-553.

5. Mendes NM, Baptista DF, Vasconcellos MC \& Schall VT (1992). Evaluation of the molluscicidal property of Euphorbia splendens var. hislopii (NEB) (Euphorbiaceae). 1. Experimental test in lentic habitat. Memórias do Instituto Oswaldo Cruz, 87: 2123

6. Baptista DF, Vasconcellos MC, Lopes FE, Silva IP \& Schall VT (1994). Perspectives of using Euphorbia splendens as a molluscicide in schistosomiasis control programs. Southeast Asian Journal of Tropical Medicine and Public Health, 25: 419424.
7. Schall VT, Vasconcellos MC, VillaçaCoelho AL, Ferreira-Lopes FE \& Silva IP (1992). Evaluation of temporal, seasonal and geographic stability of the molluscicidal property of Euphorbia splendens latex. Revista do Instituto de Medicina Tropical de São Paulo, 43: 183-191.

8. Oliveira-Filho $E$, Otto SS \& Paumgartten FJR (1995). Ecotoxicity of the molluscicidal latex of Crown-of-Thorns (Euphorbia milii var. hislopii). Proceedings of the $V$ International Symposium on Schistosomiasis. September, 10-13, Salvador, BA, Brazil, 77 (Abstract).

9. Salewski E (1964). Färbemethoden zum makroskopischen Nachweis von Implantationsstellen am Uterus der Ratte. Naunyn-Schmiedeberg's Archiv für Experimentelle Pathologie und Pharmakologie, 247: 367.

10. Sterz H (1977). Routine examination of rat and rabbit fetuses for malformations of internal organs: combination of Barrow's and Wilson's methods. In: Neubert D, Merker HJ \& Kwasigroch TE (Editors), Methods in Prenatal Toxicology. Georg Thieme Verlag, Stuttgart, 113-122.

11. Dawson AB (1926). A note on the staining of the skeleton of cleared specimens with Alizarin red S. Stain Technology, 1: 123124.

12. Delgado IF, Carvalho RR, Nogueira ACMA, Mattos AP, Figueiredo LH, Oliveira SHP, Chahoud I \& Paumgartten FJR (1993). Study on embryo-foetotoxicity of $ß$-myrcene in the rat. Food and Chemical Toxicology, 31: 31-35.
13. Paumgartten FJR, Souza CAM, Carvalho RR \& Chahoud I (1995). Embryotoxic effects of misoprostol in the mouse. Brazilian Journal of Medical and Biological Research, 28: 355-361.

14. Araujo IB, Souza CAM, De-Carvalho RR Kuriyama SN, Rodrigues RP, Vollmer RS, Alves EN \& Paumgartten FJR (1996). Study of the embryofoetotoxicity of $\alpha$ terpinene in the rat. Food and Chemical Toxicology, 34: 477-482.

15. Manson JM \& Kang YJ (1994). Test methods for assessing female reproductive and developmental toxicology. In: Wallace Hayes A (Editor), Principles and Methods of Toxicology. 3rd edn. Raven Press, New York, 989-1037.

16. Khera KS (1984). Maternal toxicity - a possible factor in fetal malformations in mice. Teratology, 29: 411-416.

17. Khera KS (1985). Maternal toxicity: a possible etiologic factor in embryo-fetal deaths and fetal malformations of rodentrabbit species. Teratology, 31: 129-136.

18. Rogers JM \& Kavlock RJ (1996). Developmental toxicology. In: Klaassen CD (Editor), Casarett \& Doull's Toxicology: The Basic Science of Poisons. 5th edn. McGraw-Hill, New York, St. Louis, San Francisco, 301-331. 